education institution and teachers of higher education institution; all the education workers can design, form and improve learning environment for bachelors and masters within the framework of Education and Science Centers, using the algorithm described in the article.

Key words: dual education system, learning environment, technology teacher, technological education, professional competence, educational process.

Дата надходження статті: 15.01.2020 p.

Рецензент: доктор педагогічних наук, професор Юрженко В. В.

\author{
УДК 378:355 \\ DOI https://doi.org/10.37915/pa.vi45.91
}

Іванченко $Є$. . А., orcid.org/0000-0003-3071-0938

Пірко Ю. О. orcid.org/0000-0002-7147-9894

\title{
СУТНІСТЬ ТА СТРУКТУРА САМООСВІТНЬОЇ КОМПЕТЕНТНОСТI МАЙБУТНЬОГО ВІЙСЬКОВОГО ІНЖЕНЕРА
}

У статті розглянуто нагальне питання освіти військових інженерів в умовах щвидкоплинного світу та необхідності виконувати службові обов'язки в невизначених умовах гібридних війн, неоднозначного вибору постійних напрямків воєнних загроз, стрімкого розвитку військового озброєння та техніки, перенесення військових конфліктів у космічний та віртуальний простори, що вимагае від випускників вищих військових навчальних закладів володіння «інструментами» для навчання, «донавчання» та перенавчання. Забезпечення такої можливості автори пов'язують з формуванням у майбутнього військового інженера самоосвітньої компетентності, під якою розуміють систему військових та технічних знань, умінь і навичок, набутих у процесі навчання у вищому військовому навчальному закладі, яка виявляеться в усвідомленні потреби до безперервного саморозвитку та самовдосконалення як в особистісній, так і у військово-професійній сферах, здатності до самостійного виявлення та виправлення «дефекту знань» у контексті новітніх розробок військової техніки та озброєння; володінні «інструментами» здобуття, обробки та критичного аналізу інформациї в соціальній та військово-професійній сферах; досвіді постійного вдосконалення та самостійного оволодіння військово-професійними знаннями та забезпечуе можливість професійної діяльності та життя в швидкозмінному суспільстві.

Також презентовано структуру самоосвітньої компетентності майбутнього військового інженера, що представлена трьома компонентами: емоційно-ціннісним, що включае потребу в саморозвитку, ставлення до самоосвіти та самовиховання, сприйняття змін; суб'єктно-особистісний, який об'єднуе здатності до самоосвіти й самовиховання, швидкої адаптації та здобуття знань особисто та в команді; професійно-організаційного, що містить вміння планувати процеси самоосвіти й самовиховання, уміння «надбудови» знань та досвід вирішення проблем професійного розвитку.

Ключові слова: майбутній військовий інженер, професійна діяльність, компетентнісний nідхід, компетенція, компетентність, самоосвітня компетентність.

Постановка проблеми. Інформаційний вибух другої половини XX сторіччя створив зовнішне середовище, у якому майбутне, як стверджував А. Тоффлер [11] ще в 1965 році, стає практично невиразним у теперішньому часі. Швидкоплинність

*(C) Іванченко $\Theta$. . A.

*C Пірко Ю. $O$.

U3 
є основною прикметою нашого життя та призводить до докорінних змін усіх його сфер - від економічної до суто особистої. Для майбутніх військових інженерів, окрім соціальних змін і руйнування звичного світу, швидкоплинність виявляеться в стрімкому прогресі озброєння й військової техніки. Разом 3 тим необхідно враховувати, що офіцерам необхідно виконувати службові обов'язки в невизначених умовах гібридних війн, неоднозначного вибору постійних напрямів воєнних загроз, перенесення військових конфліктів у космічний та віртуальний простори.

Є цілком визначені вимоги до формування змісту вищої військової освіти, який має враховувати пріоритети національних інтересів і національної безпеки; зміни, що відбуваються в економіці, політиці, соціальних відносинах і суспільній свідомості; новітні досягнення науки, техніки, технологій і культури, що забезпечують широкий науковий кругозір військового фахівця; перспективи розвитку воєнної науки, озброєння та військової техніки, способів ведення збройної боротьби [9].

За час навчання у вищому військовому навчальному закладі (ВВН3) ми маємо підготувати майбутніх військових інженерів до професійної діяльності у світі, про який самі маємо досить приблизне уявлення, та маємо враховувати, що свої службові обов'язки вони мають виконувати під час як повсякденної, так і бойової діяльності. А це означає, що кожен випускник військової спеціальності має отримати не «набір» знань, а систему, яка включає базис знань, засоби виявлення «дефекту» знань, уміння здобуття знань або самостійно, або в команді, їхньої систематизації та «надбудови» на засвоєному під час навчання базисі. Разом 3 названою системою майбутній військовий інженер має набути готовність до змін та навички швидкої адаптації до стохастичних реалій.

Отже, ми маємо надати курсантам умотивованість та «інструменти» задля мождивості після проходження курсу професійної підготовки вчитися, «довчатися» та перенавчатися, інакше кажучи - мотивацію та засоби самоосвіти та самовиховання, або, якщо застосовувати термінологію попудярного нині компетентнісного підходу, сформувати в курсантів під час навчання у ВВНЗ самоосвітню компетентність майбутнього військового інженера.

Адже згідно з дослідженням О. Чеботарьової [10], самоосвітня компетентність має виняткову соціальну та особистісну значущість для майбутнього фахівця будь-якої сфери, яка полягає, по-перше, у забезпеченні академічної мобільності студента, його готовності засвоїти програму вищої професійної освіти; по-друге, у забезпеченні професійної мобільності особистості випускника, здатного й надалі не тільки розвивати свої професійні навички, підвищувати кваліфікацію, а й змінити спеціальність, сферу своєї професійної діяльності; по-третє, у сприянні підвищенню якості роботи вищого навчального закладу, соціального інституту, закликаного реалізовувати програму вищої освіти.

Аналіз досліджень. У нашому дослідженні ми спирались на роботи науковців, присвячені компетентносному підходу. Таку діяльність здійснювали О. Андреєв; В. Баркасі; Н. Бібік; О. Бондаревська; Е. Зеєр; Л. Карпова; А. Хуторський; О. Овчарук; О. Петров; Д. Равен та ін.), також цікавими є наробки Н. Бухлової, Ю. Демченко, Н. Довматович, I. Зимньої, О. Коваленко, П. Підкасистого, М. Поднебесової, Ю. Прищупи, В. Сластьоніна, О. Хуторського, О. Чеботарьової та ін. щодо висвітлення феномену «самоосвітня компетентність».

Однак, не зважаючи на досить грунтовне та повне розкриття феномену «самоосвітня компетентність» та розроблення шляхів іï формування в процесі навчання школярів та студентів різноманітних спеціальностей, спеціального дослідження щодо обгрунтування поняття «самоосвітня компетентність майбутнього військового інженера» та виявлення шляхів іiі формування в навчально-виховному середовищі вищого військового навчального закладу проведено не було. 
Метою статті є оприлюднення результатів теоретичного дослідження щодо виявдення сутності та структури поняття «самоосвітня компетентність майбутнього військового інженера».

Викдад основного матеріалу. Вихідними поняттями дослідження є «компетентнісний підхід», «компетенція» та «компетентність». Отже, необхідно визначитись, що ми будемо розуміти під зазначеними феноменами в межах нашого дослідження.

Спираючись на аналіз наукових джерел (О. Андреєв; В. Баркасі; Н. Бібік; О. Бондаревська; Е. Зеєр; Л. Карпова; А. Хуторський; О. Овчарук; О. Петров; Д. Равен та ін.) та власне розуміння проблеми, визначимо компетентнісний підхід до професійної підготовки як спрямованість освітнього процесу на формування і розвиток компетентності майбутнього фахівця.

Визначальними складниками компетентнісного підходу є компетенції та компетентності. На підставі зіставлення думок і погдядів щодо понять «компетенція» та «компетентність» у межах нашого дослідження зупинимося на таких означеннях:

- компетенція - система знань, умінь і навичок, ціннісних орієнтацій та взаємин, особистісних якостей, досвіду, набутих у процесі навчання та соціалізації, який забезпечує готовність до діяльності в певній сфері.

- компетентність - система професійних знань, умінь, навичок, ціннісних орієнтацій та взаємин, особистісних якостей, досвіду, набутих у процесі діяльності в певній сфері, який забезпечує здатність людини діяти як у звичайній ситуації, так і в ситуації невизначеності [4].

Зауважимо, що компетентність виступає як усталена соціальна та освітня цінність, зміст якої динамічний і залежить від потреб соціально-освітньої ситуації. Актуальне розуміння поняття компетентності включає всі суб'єктні властивості особистості, що виявляються в діяльності та забезпечують їі ефективність.

Грунтовного аналізу в межах нашого дослідження потребують набутки вчених щодо феномену «самоосвітня компетентність». Вивченню даного феномену присвятиди свої праці Н. Бухлова, Ю. Демченко, Н. Довматович, І. Зимня, О. Коваленко, П. Підкасистий, М. Поднебесова, Ю. Прищупа, В. Сластьонін, О. Хуторський, О. Чеботарьова та ін.. Зазначимо, що попри докладне дослідження дефініції «самоосвітня компетентність» для різноманітних спеціальностей, самоосвітня компетентність майбутнього військового інженера не була предметом спеціального вивчення.

Зупинимось на деяких аспектах проведеного теоретичного дослідження.

Як здатність учитися впродовж життя, основу неперервного навчання в контексті як особистого професійного, так i соціального життя розглядає самоосвітню компетентність І. Зимня [5]. До змісту цієї здатності особистості дослідниця відносить:

- потребу в саморозвитку;

- уміння вибудовувати персональну життєву стратегію;

- єдність інтелектуального розвитку з формуванням особистості, здатність долати протиріччя й невизначеності свого життєвого досвіду;

- здатність самостійно контродювати хід свого інтелектуального розвитку, досягати висот професійної майстерності та творчості;

- структурування знань, ситуативно-адекватна актуалізація знань, розширення,

- збільшення накопичених знань: мовленнєвий і мовний розвиток іноземної мови, овододіння культурою рідної мови;

- адекватна оцінка досягнутих у саморозвитку резудьтатів і постановка нових перспективних завдань.

Їі думку продовжує М. Поднебесова та визначає самоосвітню компетентність як особистісно-професійну якість, яка характеризуе спеціаліста як суб'єкта здатного до самостійної організації пізнавальної діяльності, спрямованої на неперервний

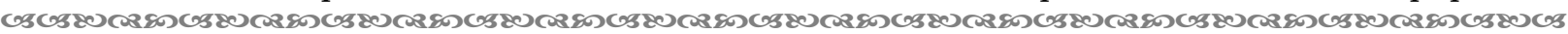
51 
саморозвиток професійних та загальнокультурних якостей та самовдосконалення [7]. Корисними для спрямування нашого дослідження є виокремлені авторкою структурні компоненти самоосвітньої компетентності: мотиваційно-смисловий, когнітивний, організаційно-діяльнісний, оцінно-рефлексивний. Акцентовано, що самоосвітня компетентність виявляється в уміннях та навичках самовдосконалення, у навичках самостійної пізнавальної діяльності, метою якої $є$ оновлення інтелектуального потенціалу особистості.

Низка науковців пов'язує самоосвітню компетентність із готовністю. Наприклад, О. Коваденко, під самоосвітньою компетентністю розуміє складну інтегративну властивість особистості, що забезпечуе готовність задовольняти індивідуальні та соціальні потреби пізнання нею дійсності на основі оволодіння знаннями, уміннями та навичками, способами діяльності та набутого досвіду продуктивно здійснювати самостійне систематичне цільове освоєння соціального досвіду дюдства. Це готовність і здатність особистості до самостійного, систематичного, цілеспрямованого пізнання дійсності, освоєння соціального досвіду людства, самореалізації, саморозвитку. Це інтегрована якість особистості, яка грунтується на вміннях самоосвітньої діяльності та визначає готовність особистості до самоосвіти, самонавчання, самовдосконадення, самовибору, самореалізації впродовж життя з усвідомленням особистих і суспільних потреб [6].

3 авторкою погоджується Ю. Прищупа, яка розглядає формування самоосвітньої компетентності майбутніх інженерів-будівельників через рівень їхньої готовності до самоосвіти в орієнтованому, змістовому, операційному, психологічному аспектах [8].

Нам імпонуе визначення самоосвітньої компетентності, надане О. Чеботарьовою, яка визначає названий феномен як інтегративну особистісну властивість, що забезпечується емоціональноцінностним ставленням до саморозвитку і самоосвітньої діяльності, системою знань щодо планування і реалізації самоосвітньої діядьності, способи самовиховання; суб'єктноособистісним досвідом продуктивного вирішення проблем розвитку, розробки і реалізації моделей підготовки студентів до самоосвітньої діяльності; готовністю до безперервного саморозвитку якостей професіонала, самовдосконалення, самоосвіти в галузі майбутньої професії [10]. Авторка вважає, що зазначена компетентність грунтуеться на досвіді самостійної діядьності та виступає одним з критеріїв оцінки якості випускника, з чим складно не погодитись.

Ю. Демченко [2], спираючись на дослідження $\quad$ І. Зимньої, П. Підкасистого, В. Сластьоніна, О.Хуторського, О. Чеботарьової та ін., розглядає самоосвітню компетентність як інтеграційну якість особистості, що характеризуе іiі здатність до систематичної самостійно організованої пізнавальної діяльності, спрямованої на безперервний саморозвиток професійних i загальнокультурних якостей і самовдосконалення, та виокремлюе такі структурні компоненти розглядуваного феномену:

- мотиваційно-особовий, що допускає наявність спонукальних мотивів студента в самоосвітній діяльності, прагнення до задоволення потреби в опануванні знань, умінь, навичок і способів самоосвітньої діяльності для свого особистісного і професійного зростання;

- когнітивний як такий, що має на увазі наявність системи знань (загальноосвітніх, предметних і професійних), умінь і навичок самоосвітньої діядьності, про методи і технології їі здійснення, готовність і здатність до безперервної самоосвіти;

- організаційно-діяльнісний, що припускає володіння уміннями самостійної організації, планування і управління самоосвітньою діяльністю, наявністю певних практичних умінь роботи з конкретними об'ектами самоосвіти;

- рефлексивний компонент, що полягає в здатності самоаналізу і самооцінки, готовності до самоосвіти, саморегуляції і контролю, адекватній оцінці результатів своєї самоосвітньої діяльності і застосуванні їх у конкретних професійних завданнях

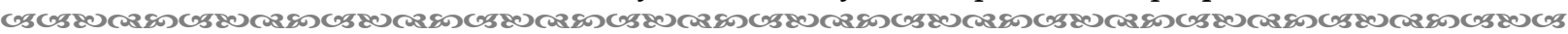
52 
і ситуаціях, які певним чином перегукуються 3 компонентами, що їх виокремила М. Поднебесова.

В унісон 3 названими авторами звучать і висновки щодо визначення досліджуваного феномену Н. Довматович [3], яка вважає, що самоосвітню компетентність складають знання, уміння й навички, що формують здатність студентів до самоосвітньої діядьності.

Н. Бухлова [1, с. 178] розглядає самоосвітню компетентність як інтегровану якість особистості, що характеризуеться наявністю певним чином організованих і структурованих знань, самоосвітніх умов i навичок, мотивів, інтересу до самовдосконалення, досвіду самостійної діяльності, спрямованістю на освіту впродовж життя, ціннісних орієнтацій, що дозволяють їй успішно вирішувати питання власних самореалізацій, самовиховання та саморозвитку, та виокремлює мотиваційний, пізнавальний, емоційно-вольовий (особистісний) й змістовно-процесуальний (технологічний) компоненти.

Віддаючи належне плеяді науковців, які займались дослідженням питань самоосвіти й самоосвітньої компетентності, та спираючись на їхні надбання і враховуючи відсутність визначення саме самоосвітньої компетентності майбутнього військового інженера, дозводимо собі сформулювати вдасні визначення понять «самоосвітня компетентність» та «самоосвітня компетентність майбутнього військового інженера».

Самоосвітня компетентність майбутнього фахівия - це система знань, умінь і навичок, набутих у процесі навчання у вищому навчальному закладі, яка виявляється в усвідомленні потреби до безперервного саморозвитку та самовдосконалення як у особистісній, так і у професійній сферах, здатності до самостійного виявлення та виправлення «дефекту знань»; вододінні «інструментами» здобуття, обробки та критичного аналізу інформації в соціальній та професійній сферах; досвіді постійного удосконалення та самостійного оволодіння професійними знаннями та забезпечує можливість професійної діяльності та життя в швидкозмінному суспільстві.

Уточнимо запропоноване визначення для майбутнього військового інженера.

Самоосвітня компетентність майбутнього військового інженера - це система військових та технічних знань, умінь і навичок, набутих у процесі навчання у вищому військовому навчадьному закладі, яка виявляється в усвідомленні потреби до безперервного саморозвитку та самовдосконалення як в особистісній, так і у військово-професійній сферах, здатності до самостійного виявлення та виправлення «дефекту знань» у контексті новітніх розробок військової техніки та озброєння; володінні «інструментами» здобуття, обробки та критичного аналізу інформації в соціальній та військово-професійній сферах; досвіді постійного удосконадення та самостійного оволодіння військово-професійними знаннями та забезпечує мождивість професійної діяльності та життя в швидкозмінному суспільстві.

Зважаючи на проведений аналіз психолого-педагогічної літератури щодо зазначеного феномену та власний досвід, можемо запропонувати структуру самоосвітньої компетентності майбутнього військового інженера, презентовану трьома компонентами: емоційно-ціннісним, що вкдючає потребу в саморозвитку, ставлення до самоосвіти та самовиховання, сприйняття змін; суб'єктно-особистісний, який об'єднуе здатності до самоосвіти й самовиховання, швидкої адаптації та здобуття знань особисто та в команді; професійно-організаційного, що містить уміння планувати процеси самоосвіти й самовиховання, уміння «надбудови» знань та досвід вирішення проблем професійного розвитку (рис. 1). 


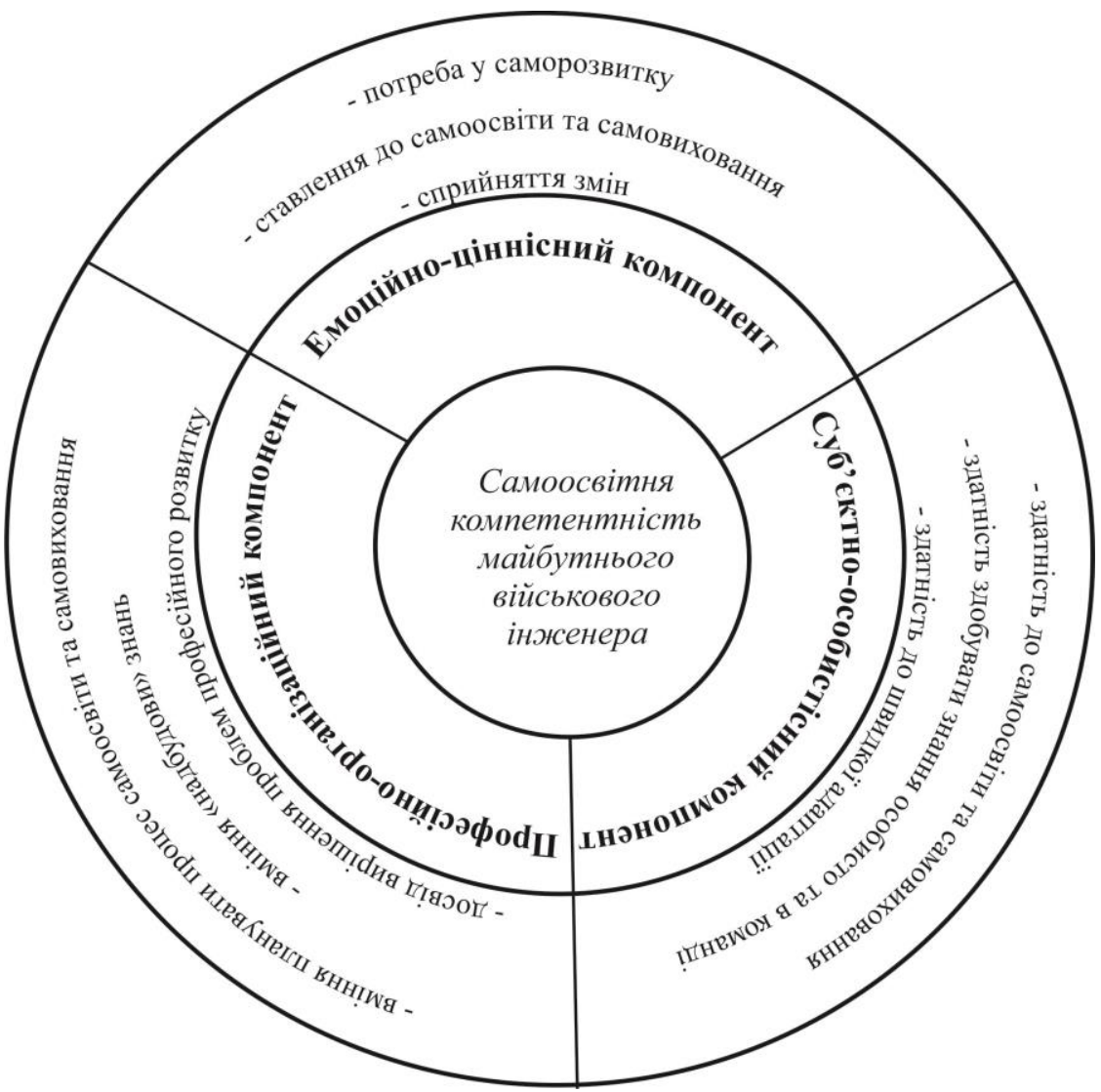

Рис. 1. Структура самоосвітньой компетентності майбутнього військового інженера

Нагодосимо на інваріантності запропонованої структури самоосвітньої компетентності майбутнього військового інженера як для фахівців інших військових спеціальностей, так і для фахівців інших сфер. Відмінність буде в змістовому наповненні структурних компонентів зазначеної компетентності.

Висновки. Таким чином, нами сформульовано визначення самоосвітньої компетентності майбутнього військового інженера та запропоновано іï структуру. Подальші розвідки вбачаємо в докладному розкритті компонентів зазначеної компетентності, визначенні умов формування названої компетентності в процесі професійної підготовки майбутніх військових інженерів у навчально-виховному просторі вищого військового навчадьного закладу, а також створенні діагностичного комплексу методик щодо оцінювання зазначеної якості.

\section{Список використаних джерел:}

1. Бухлова Н. В. Психолого-педагогічні умови підготовки вчителів до формування самоосвітньої компетентності вчителів у процесі післядипломної педагогічної освіти. Науковий часопис Національною педагогічного університету імені М. П. Арагоманова. Серія 16: Творча особистість учителя: проблеми теорії і практики. 2007. № 7 (17). С. 174-179.

2. Демченко Ю. Самоосвітня компетентність - невід'ємна складова частина професійної компетентності (діяльності) майбутнього учителя. Актуальні питання гуманітарних наук. 2019. № 23, том 1. С. 154-159.

3. Довмантович Н. Проблема формування самоосвітньої компетентності особистості у педагогічній теорії. Проблеми підготовки сучасного вчителя. 2015. № 12. С. 139-144.

4. Іванченко Є. А. Сутність та структура мультиплікативної компетентності майбутнього економіста. Науковий вісник Південноукраїнського державного педагогічного університету ім. К. Д. Уиинського. 2011. № 11-12. С. 144-155. 
5. Зимняя И. А. Компетентностный подход. Каково его место в системе современных подходов к проблемам образования? (теоретико-методологический аспект). Высшее образование сегодня. 2006. № 4. C. 20-27.

6. оваленко О. Е., Брюханова Н. О., Мельниченко О. О. Теоретичні засади професійної педагогічної підготовки майбутніх інженерів-педагогів в контексті приєднання України до Болонського процесу. Харків: УІПА, 2007. 162 с.

7. Поднебесова М. И. Сущностные характеристики самообразовательной компетентности. (2015. 28 декабря) URL: https://econf.rae.ru/article/7457.

8. Пришупа Ю. Ю. Формування майбутніх інженерів-будівельників у процесі професійної підготовки : дис. ... канд. пед. наук : 13.00 .04 / Національний авіаційний університет. Київ, 2016. 227 c.

9. Про затвердження Положення про особливості організації освітньої діяльності у вищих військових навчальних закладах Міністерства оборони України та військових навчальних підрозділах закладів вищої освіти: Наказ Міністерства оборони України 09 січня 2020 року № 4. URL: https://zakon.rada.gov.ua/laws/show/z0250-20.

10. Чеботарева Е. С. Самообразовательная компетентность будущего специалиста как критерий качества его подготовки. 2009. URL: https://cyberleninka.ru/article/v/samoobrazovatelnayakompetentnostbuduschego- spetsialista-kak-kriteriy-kachestva-ego-podgotovki/.

11. Toffler Alvin. The Future as a Way of Life. 1965. URL: http://www.benlandau.com/wpcontent/uploads/2015/06/Toffler-1965-The-future-as-a-way-of-life.pdf.

\section{References:}

1. Bukhlova, N. V. (2007). Psykholoho-pedahohichni umovy pidhotovky vchyteliv do formuvannia samoosvitnoi kompetentnosti vchyteliv u protsesi pisliadyplomnoi pedahohichnoi osvity [Psychopedagogical conditions of teachers' preparation for the formation of teachers' self-educational competence in the process of postgraduate pedagogical education]. Naukovyi chasopys Natsionalnoiu pedahohichnoho universytetu imeni M. P. Drahomanova. Seriia 16: Tvorcha osobystist uchytelia: problemy teorii i praktyky, 7 (17), 174-179 [in Ukrainian].

2. Demchenko, Yu. (2019). Samoosvitnia kompetentnist - nevidiemna skladova chastyna profesiinoi kompetentnosti (diialnosti) maibutnoho uchytelia [Self-education competence is an integral part of the future teacher's professional competence (activity)]. Aktualni pytannia humanitarnykh nauk, 23, 1, 154-159. doi // 10.24919/2308-4863.1/23.166160 [in Ukrainian].

3. Dovmantovych, N. (2015). Problema formuvannia samoosvitnoi kompetentnosti osobystosti u pedahohichnii teorii [The problem of the formation of self-educational competence of the personality in pedagogical theory]. Problemy pidhotovky suchasnoho vchytelia, 12, 139-144 [in Ukrainian].

4. Ivanchenko, Ye. A. (2011). Sutnist ta struktura multyplikatyvnoi kompetentnosti maibutnoho ekonomista [Essence and structure of the future economist's multiplicative competence]. Naukovyi visnyk Pivdennoukrainskoho derzhavnoho pedahohichnoho universytetu im. K. D. Ushynskoho, 11-12, 144-155 [in Ukrainian].

5. Zimnyaya, I. A. (2006). Kompetentnostnyiy podhod. Kakovo ego mesto v sisteme sovremennyih podhodov $\mathrm{k}$ problemam obrazovaniya? (teoretiko-metodologicheskiy aspekt) [A competencybased approach. What is its place in the system of modern approaches to the problems of education? (theoretical and methodological aspect)]. Vyisshee obrazovanie segodnya, 4, 20-27 [in Russian].

6. Kovalenko, O. E., Briukhanova, N. O., \& Melnychenko, O. O. (2007). Teoretychni zasady profesiinoi pedahohichnoi pidhotovky maibutnikh inzheneriv-pedahohiv $v$ konteksti pryiednannia Ukrainy do Bolonskoho protsesu [Theoretical principles of future engineers-educators' professional pedagogical training in the context of Ukraine's accession to the Bologna process]. Kharkiv: UIPA [in Ukrainian].

7. Podnebesova, M. I. (2015, December 28). Suschnostnyie harakteristiki samoobrazovatelnoy kompetentnosti [Essential characteristics of self-educational competence]. Retrieved from http://econf.rae.ru/article/7457 [in Russian].

8. Pryshupa, Yu. Yu. (2016). Formuvannia maibutnikh inzheneriv-budivelnykiv u protsesi profesiinoi pidhotovky [The formation of future civil-engineers' self-educational competence in the process of professional education]. (Candidate's thesis). National Aviation University. Kyiv [in Ukrainian]. 
9. On approval of the Regulation on the peculiarities of educational activity organization in higher military educational institutions of the Ministry of Defence of Ukraine and military training units of higher educational institutions. Order of the Ministry of Defence of Ukraine from January 9, 2020, No. 4. Retrieved from https://zakon.rada.gov.ua/laws/show/z1126-15 [in Ukrainian].

10. Chebotareva, E. S. (2009). Samoobrazovatelnaya kompetentnost buduschego spetsialista kak kriteriy kachestva ego pidgotovki [The future specialist's self-educational competence as a criterion for the quality of his/her training]. Retrieved from https://cyberleninka.ru/article/v/samoobrazovatelnaya-kompetentnostbuduschego-spetsialistakak-kriteriy-kachestva-ego-podgotovki/ [in Russian].

11. Toffler, A. (1965). The Future as a Way of Life. Retrieved from http://www.benlandau.com/wpcontent/uploads/2015/06/Toffler-1965-The-future-as-a-way-of-life.pdf [in English].

\section{Ivanchenko Ie. A., orcid.org/0000-0003-3071-0938 \\ Pirko Yu. O., orcid.org/0000-0002-7147-9894 \\ ESSENCE AND STRUCTURE OF FUTURE MILITARY ENGINEER'S SELF-EDUCATIONAL COMPETENCE}

The article deals with the urgent issue of military engineers' education in the context of the fastpaced world and the need to perform official duties in the uncertain conditions of hybrid wars, ambiguous choice of permanent directions of military threats, rapid development of military weapons and technology, transfer of military conflicts to cosmos and virtual space requiring graduates of higher military educational establishments to possess "tools" for training, "continuing education" and "retraining".

Providing this opportunity, the authors associate with the formation of a future military engineer's self-education competence by which is understood the system of military and technical knowledge, practical abilities and skills acquired in the proses of education at a higher military educational establishment, which is manifested in the need for continuous self-development and selfimprovement in the personal as well as in the military professional sphere, the ability to independently identify and correct the "knowledge defect" in the context of the latest developments in military equipment and armament; possessing "tools" for obtaining, processing and critical analysis of information in the social and military professional fields; experience of continuous improvement and self-mastery of military professional knowledge; a future military engineer's self-education competence provides an opportunity for professional activity and life in a rapidly changing society.

The structure of the future military engineer's self-educational competence has been presented. It has been represented by three components: the emotional-value component, which includes the need for self-development, the attitude to self-education and self-upbringing, perception of change; the subject-to-personal component, which combines the ability to educate and self-educate, to adapt quickly and acquire knowledge personally and in a team; the professional-organizational component, which contains the ability to plan processes of self-education and self-upbringing, the ability to "upgrade" knowledge and experience in solving problems of professional development.

Key words: future military engineer, professional activity, competency-based approach, competency, competence, self-educational competence. 